\title{
Presenilin-Dependent $\gamma$-Secretase-Mediated Control of p53-Associated Cell Death in Alzheimer's Disease
}

\author{
Cristine Alves da Costa, ${ }^{1}$ Claire Sunyach, ${ }^{1 \star}$ Raphaelle Pardossi-Piquard, ${ }^{1 \star}$ Jean Sévalle, ${ }^{1}$ Bruno Vincent, ${ }^{1}$ \\ Nicole Boyer, ${ }^{\dagger, 1}$ Toshitaka Kawarai, ${ }^{2}$ Nadège Girardot, ${ }^{3}$ Peter St. George-Hyslop, ${ }^{2}$ and Frédéric Checler ${ }^{1}$ \\ ${ }^{1}$ Institute of Molecular and Cellular Pharmacology, Team Foundation for Medical Research, Coeducational Unit of Research 6097, National Center of \\ Scientific Research/Nice-Sophia-Antipolis University, 06560 Valbonne, France, ${ }^{2}$ Center for Research in Neurodegenerative Diseases, Department of \\ Medicine, University of Toronto and University Health Network, Toronto, Ontario, Canada, and ${ }^{3}$ National Institute of Health and Medical Research Unit \\ 289, Pitié-Salpêtrière Hospital, Paris, France
}

Presenilins (PSs) are part of the $\gamma$-secretase complex that produces the amyloid $\beta$-peptide (A $\beta$ ) from its precursor $[\beta$-amyloid precursor protein ( $\beta$ APP)]. Mutations in PS that cause familial Alzheimer's disease (FAD) increase $\mathrm{A} \beta$ production and trigger p53-dependent cell death. We demonstrate that PS deficiency, catalytically inactive PS mutants, $\gamma$-secretase inhibitors, and $\beta$ APP or amyloid precursor protein-like protein 2 (APLP2) depletion all reduce the expression and activity of p53 and lower the transactivation of its promoter and mRNA expression. 53 expression also is diminished in the brains of PS- or $\beta$ APP-deficient mice. The $\gamma$ - and $\varepsilon$-secretase-derived amyloid intracellular C-terminal domain (AICD) fragments (AICDC59 and AICDC50, respectively) of $\beta$ APP trigger p53-dependent cell death and increase p53 activity and mRNA. Finally, PS1 mutations enhance p 53 activity in human embryonic kidney 293 cells and p53 expression in FAD-affected brains. Thus our study shows that AICDs control p53 at a transcriptional level, in vitro and in vivo, and that FAD mutations increase p53 expression and activity in cells and human brains.

Key words: presenilins; $\gamma$-secretase; AICD; apoptosis; p53; Alzheimer’s disease

\section{Introduction}

Several studies have reported on an increased p53-like immunoreactivity in sporadic Alzheimer's disease $(\mathrm{AD})$, especially in a subpopulation of cortical neurons undergoing degeneration (de la Monte et al., 1997; Kitamura et al., 1997; Garcia-Ospina et al., 2003; Ohyagi et al., 2005), but the cellular mechanisms by which p53 expression could be altered in AD remained puzzling. Presenilin 1 (PS1) and PS2, together with nicastrin, anterior pharynx defective-1 (Aph-1), and presenilin enhancer-2 (Pen-2), form high-molecular-weight complexes that are necessary for the intramembranous proteolysis of several type 1 transmembrane

\footnotetext{
Received Feb. 14, 2006; revised April 27, 2006; accepted April 30, 2006.

This work was supported by the National Center of Scientific Research, by the United for Alzheimer's Disease Research Foundation, by the Foundation for Medical Research, and by European Union contract LSHM-CT-2003503330 (APOPIS). R.P.-P. was supported by the Association France Alzheimer, and C.S. was supported by the Foundation for Medical Research. We are grateful to Drs. B. de Strooper (Leuven, Belgium), P. Saftig (Gottingen, Germany), F. Chen (Toronto, Ontario, Canada), M. Roussel (Memphis, TN), Jie Chen (Harvard University, Boston, MA), and U. Müeller (Heidelberg, Germany) for providing cells and brain samples. We warmly thank Drs. M. Oren (Rehovot, Israel) and B. Vogelstein (Baltimore, MD) for supplying the p53 promoters and PG13 vectors, respectively. We also thank Drs. C. Dumanchin and D. Campion (Rouen, France) for providing human brain samples. This work is dedicated to our friend and colleague, Nicole Boyer, who died suddenly.

${ }^{\dagger}$ Deceased, April 19, 2005

${ }^{*}$ C.S. and R.P.-P. contributed equally to this work.

Correspondence should be addressed to either of the following: Dr. Frédéric Checler, Institute of Molecular and Cellular Pharmacology, Coeducational Unit of Research 6097, National Center of Scientific Research/National Union of Autonomous Syndicates, 660 Route des Lucioles, Sophia Antipolis, 06560 Valbonne, France, E-mail: checler@ipmc.cnrs.fr; or Dr. Cristine Alves da Costa, Institute of Molecular and Cellular Pharmacology, Coeducational Unit of Research 6097, National Center of Scientific Research/National Union of Autonomous Syndicates, 660 Route des Lucioles, Sophia Antipolis, 06560 Valbonne, France, E-mail: acosta@ipmc.cnrs.fr.

DOI:10.1523/JNEUROSCI.0651-06.2006

Copyright $\odot 2006$ Society for Neuroscience $\quad 0270-6474 / 06 / 266377-09 \$ 15.00 / 0$
}

proteins (termed $\gamma$-secretase cleavage) (for review, see De Strooper, 2003). Many of these $\gamma$-secretase substrates (e.g., Notch, p75) are involved in biologically important signal transduction pathways. Mutations in PS1 or PS2 in humans cause AD (Checler, 1999), a prevalent lethal adult-onset neurodegenerative disease characterized by progressive dementia, cerebral amyloid $\beta(\mathrm{A} \beta)$ peptide deposition, and widespread neuronal death in the brain. These mutations alter the processing of one of the $\gamma$-secretase substrates $[\beta$-amyloid precursor protein $(\beta \mathrm{APP})]$, generating increased amounts of a neurotoxic proteolytic fragment (termed A $\beta$ ) (Checler, 1995). Furthermore, primary cultured hippocampal neurons prepared from mice harboring mutant PS1 exhibit increased vulnerability to apoptosis and activated caspase (Guo et al., 1999). Several studies have shown that mutations in PS2 enhance susceptibility to cell death (Wolozin et al., 1996; Alves da Costa et al., 2002), likely via a p53dependent mechanism (Alves da Costa et al., 2002). However, it is presently unclear whether this neuronal death is simply a direct consequence of the accumulation of neurotoxic $\mathrm{A} \beta$ or whether cell death also occurs because other signaling pathways are perturbed as well. We therefore investigated a possible direct link between PS-associated $\gamma$-secretase activity and the control of cell death.

\section{Materials and Methods}

Biochemical analysis of $p 53$ in human and murine brain tissues. Biochemical analysis of p53 immunoreactivity was performed on frontal cortices from normal and AD-affected human brains. Samples from Rouen (France) correspond to a control brain (female, 74 years old) and one 
familial AD (FAD) brain (female, 51 years old, Leu ${ }^{392}$ Val-PS1 mutation). Samples from la Pitié-Salpêtrière (Paris, France) correspond to two control brains (males, 74 and 55 years old) without history of dementia or other neurological disease (Braak stage 0 ), and two FAD brains [female, 37 years old, Leu ${ }^{235}$ Pro-PS1 mutation; male, 44 years old, Phe ${ }^{386}$ Ser-PS1 mutation, Braak stage VI (supplemental table, available at www.jneurosci.org as supplemental material )]. The mean postmortem delay was $27.8 \pm 7.1 \mathrm{~h}$. PS1/PS2 double knock-out murine brains have been described recently (Saura et al., 2004).

p53 expression, activity, and promoter transactivation. Cellular p53 immunoreactivity was analyzed by Western blot, using a 1:10,000 dilution of an anti-p53 mouse monoclonal antibody (Santa Cruz Biotechnology, Santa Cruz, CA) in nuclear extracts prepared as previously described for cytochrome $c$ translocation experiments (Alves da Costa et al., 2002) while murine brain p53 was analyzed in total homogenates, using the conditions described above. The activity of p53 was measured after transient transfection of the PG13-luciferase (PG13) cDNA kindly provided by Dr. B. Vogelstein (Baltimore, MD). This construction is based on the genomic DNA consensus sequence recognized by p 53 on its target genes (El-Deiry et al., 1992). The transcriptional activation of the $\mathrm{p} 53$ promoters was measured after transfections of cDNAs harboring the murine p53 promoter (mPP) (Ginsberg et al., 1990) or human p53 promoter (hPP) sequences in-frame with luciferase (provided by Dr. M. Oren, Rehovot, Israel). All activities were measured after cotransfection of $0.5-1 \mu \mathrm{g}$ of the above cDNAs and $0.25-0.5 \mu \mathrm{g}$ of $\beta$-galactosidase ( $\beta$-gal) cDNA to normalize transfection efficiencies. Importantly, because p53 could be affected by cell density (Bar et al., 2004), all experiments were performed at a $60-70 \%$ cell density.

Real-time quantitative PCR. Total RNA from cells was extracted at the indicated times, using the RNeasy kit and following the instructions from the manufacturer (Qiagen, Hilden, Germany). After treatment with DNase I, $2 \mu \mathrm{g}$ of total RNA was reverse transcribed, using oligo-dT priming and avian myeloblastosis virus reverse transcriptase (Promega, Madison, WI). Real-time PCR was performed in an ABI PRISM 5700 Sequence Detector System (Applied Biosystems, Foster City, CA), using the SYBR Green detection protocol as outlined by the manufacturer. Gene-specific primers were designed by using the Primer Express software (Applied Biosystems). Relative expression level of target genes was normalized for RNA concentrations with two different house keeping genes [human glyceraldehyde phosphate dehydrogenase (GAPDH), mouse $\gamma$-actin] according to the cell specificity. mRNA values are expressed as arbitrary units, represent the mean \pm SD of triplicates, and are representative of three to five independent experiments.

In the experiments dedicated to the analysis of p 53 mRNA stability, human embryonic kidney 293 (HEK 293) cells were transiently transfected with empty or [amyloid intracellular C-terminal domain C59encoding (AICDC59-encoding)] pcDNA3 vector. At $33 \mathrm{~h}$ after transfection the cells were treated with $10 \mu \mathrm{g} / \mathrm{ml}$ of actinomycin $\mathrm{D}$ for various time periods; then total RNA was extracted by using the RNeasy kit, reverse transcribed, and submitted to real-time PCR as described above.

AICD-induced caspase 3 activation. Wild-type fibroblasts were transfected with empty or AICDC59 coding vectors, alone or in combination with Tat interactive protein 60 (Tip60) and family B, member 1 (Fe65) cDNA, using Lipofectamine 2000 (Invitrogen, Cergy-Pontoise, France) according to the manufacturer's recommendation. At $36 \mathrm{~h}$ after transfection the cells were treated for $16 \mathrm{~h}$ at $37^{\circ} \mathrm{C}$ with $10 \mu \mathrm{M}$ of pifithrin- $\alpha$, an inhibitor of p53 transcriptional activity (Komarov et al., 1999) or an inactive analog (kindly provided by M. P. Mattson, Johns Hopkins Hospital and University School of Medicine, Baltimore, MD). Cells subsequently were incubated for $2 \mathrm{~h}$ at $37^{\circ} \mathrm{C}$ in the presence or absence of $1 \mu \mathrm{M}$ staurosporine (Sigma, St. Quentin-Fallavier, France). Cell were lysed in Luria-Bertani (LB) buffer [containing the following (in mM): 25 HEPES, $\mathrm{pH} 7.5,5 \mathrm{MgCl}_{2}, 5 \mathrm{EDTA}, 5 \mathrm{DTT}$ ], and caspase 3 activity was measured as previously described (Alves da Costa et al., 2003). To analyze AICDC59like immunoreactivity, we resolved $40 \mu \mathrm{g}$ of proteins of the same cell lysate on 16\% Tris-tricine gel, transferred them onto Hybond C membrane, and probed them with BR188 polyclonal antibody that recognizes the extreme $\mathrm{C}$ terminus of $\beta$ APP (kind gift from M. Goedert, Medical Research Council, Cambridge, UK). Fe65- and Tip60-like immunoreac- tivities were analyzed as described previously (Pardossi-Piquard et al., 2006).

Human brain preparation and immunohistochemical analysis of p53. Immunohistochemical analysis of p53 was performed on the temporal cortex of the above control and FAD. The brains were fixed by immersion in buffered formaldehyde ( $10 \%$ of the commercial solution) for at least 1 month. Samples from isocortex (Brodmann area 22) were embedded in paraffin. Sections $7 \mu \mathrm{m}$ thick were obtained. After removal of the paraffin and after rehydration the sections were pretreated in boiled citrate buffer, $\mathrm{pH} \mathrm{6,} \mathrm{for} \mathrm{two} \mathrm{cycles} \mathrm{of} 10 \mathrm{~min}$. Endogenous peroxidases then were quenched by a solution of $\mathrm{H}_{2} \mathrm{O}_{2}(3 \%)$ for $10 \mathrm{~min}$. Slices were left for 60 min in a solution of Tris-buffered saline (TBS) containing Tween 20 $(0.5 \%)$ and bovine serum albumin $(2 \%)$ to limit nonspecific fixation of the antibody. Sections were incubated overnight with a 1:500 solution of p53 antibody (clone sc-98, Santa Cruz) at room temperature. The biotinylated secondary antibody and the solution of streptavidin-peroxidase (ChemMate kit; Dako, High Wycombe, UK) were applied for 25 min. Immunological complexes were revealed by diaminobenzidine (DAB). Between each step the sections were rinsed in TBS containing $0.5 \%$ of Tween 20 . Slides were counterstained with Harris hematoxylin, dehydrated, and mounted in DPX medium. Three slides of each sample were immunolabeled. A total of 200 neuronal profiles per slide were identified with the use of a $40 \times$ objective. The proportion of neuronal profiles immunolabeled by 53 antibody was compared between patients and controls, using ANOVA (model I, fixed, and Fisher's protected least significant difference for post hoc comparisons between groups).

\section{Results \\ Presenilin deficiency lowers p53 transcription in vitro and in vivo}

p53 is a tumor suppressor protein involved in the direct transcriptional activation of a series of pro-apoptotic effectors such as caspase 1 (Gupta et al., 2001) and the oncogene bax (Miyashita and Reed, 1995). This DNA binding protein is sequence-specific, and a consensus binding site sequence had been delineated (ElDeiry et al., 1992). We have used this sequence in-frame with a luciferase reporter gene (referred to as PG13) as a means to monitor p53 functional activity (El-Deiry et al., 1992). In PS1- and PS2-deficient (PS-deficient) fibroblasts and in PS-deficient blastocysts there was a reduction in the amount of $\mathrm{p} 53$ protein in nuclear extracts (Fig. $1 A-C$ ) and, as would be expected, an overall decrease in p53 activity (Fig. $1 D$ ). In agreement with these data, in vivo $\mathrm{p} 53$ protein expression was significantly lower in brains of mice in which expression of both PS1 and PS2 had been abolished (Saura et al., 2004) by conditional knock-out $(46.7 \pm 2.9 \%$ of control brains; $n=5$; $p<0.05$ ) (Fig. $1 E$ ).

To assess whether the observed reductions in p53 protein expression resulted from decreased p53 mRNA transcription, we used a previously described construct (Ginsberg et al., 1990) that harbors the $\mathrm{mPP}$ region in-frame with a luciferase reporter gene. These experiments confirmed that the reductions of p53 immunoreactivity and p53 activity were accompanied by a decrease in the transactivation of the p53 promoter in both PS-deficient fibroblasts and blastocysts (Fig. $1 F$ ). In good agreement with these results, p53 mRNA level analyses by real-time PCR indicated that endogenous p53 mRNA levels were significantly lower in PSdeficient fibroblasts than in wild-type fibroblasts (Fig. $1 F$ ).

\section{PS2 and N141I-PS2 increase p53 activity and promoter transactivation}

We and others previously established that PS2 triggered cell death (Araki et al., 2001; Alves da Costa et al., 2002) via a p53dependent pathway (Alves da Costa et al., 2002). We therefore examined the weight of the contribution of PS2 in the alteration of p53 observed after depletion of both PSs. Overall, PS2 deple- 


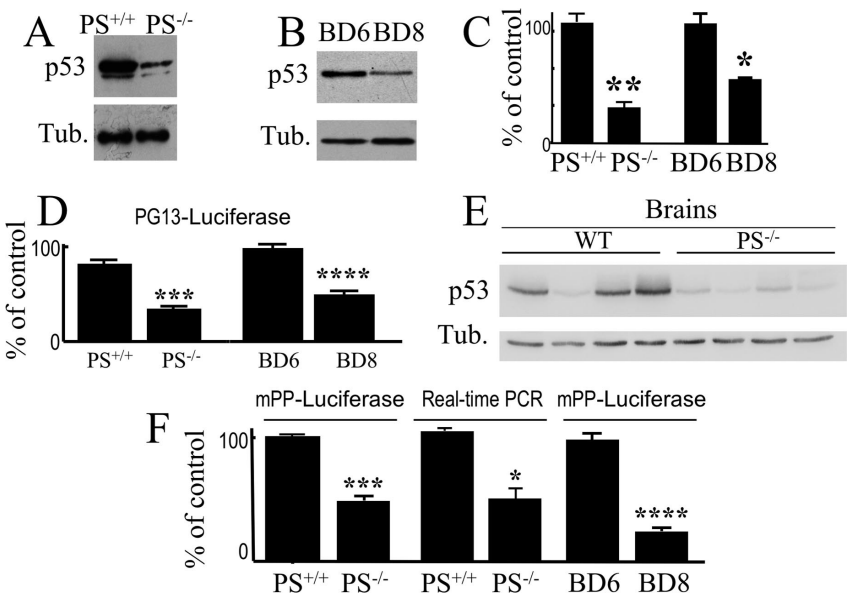

Figure 1. Influence of PS deficiency on $\mathrm{p} 53$ in vitro and in vivo. $\boldsymbol{A}, \boldsymbol{B}, \mathrm{p} 53$ immunoreactivity in nuclear extracts of wild-type (PS $\left.{ }^{+/+}, B D 6\right)$ or PS-deficient $\left(\mathrm{PS}^{-1-}, \mathrm{BD} 8\right)$ fibroblasts $(A)$ or blastocysts $(\boldsymbol{B})$. C, The bars correspond to densitometric analyses of $\mathrm{p} 53$ in the indicated cell line expressed as a percentage of $p 53$ immunoreactivity in the corresponding wild-type cell line and are the means \pm SEM of three independent determinations. D, p53 activity assessed by transient cotransfection of $\beta$-galactosidase and PG13-luciferase CDNA in the indicated fibroblast and blastocyst cell lines as described in Materials and Methods. Bars correspond to the ratios of luciferase/ $\beta$-galactosidase activities (see Materials and Methods) expressed as a percentage of control activities monitored in PS ${ }^{+/+}$or BD6 and are the means \pm SEM of six independent determinations. $\boldsymbol{E}, \mathrm{p} 53$ immunoreactivity measured in whole proteic extracts prepared from wild-type (WT) or double-conditional PS knock-out (PS ${ }^{-1-}$ ) mice brains. $\boldsymbol{F}$, Transactivation of the $p 53$ promoter and real-time $P C R$ analysis of $p 53$ mRNA. p53 promoter transactivation was measured after transfection of the mPP-luciferase construct in the indicated fibroblast and blastocyst cell lines. Bars correspond to the ratios of luciferase/ $\beta$-galactosidase activities expressed as a percentage of control activities monitored in PS ${ }^{+/+}$or BD6 and are the means \pm SEM of six independent determinations. Real-time PCR analysis was performed in the indicated fibroblastic cell lines. Bars correspond to the means \pm SEM of three independent determinations. ${ }^{*} p<0.05$; ${ }^{* *} p<0.01 ;{ }^{* * *} p<0.0005$; ${ }^{* * * *} p<0.0001$.

tion fully mimicked the phenotype observed after both PS1 and PS2 depletion. Thus PS2 overexpression drastically increased p53 activity, expression, and promoter transactivation (supplemental Fig. $1 A, B$, available at www.jneurosci.org as supplemental material). Conversely, PS2 depletion led to reduced p53 activity and expression and lowered the transactivation of p53 promoter (supplemental Fig. 1C,D, available at www.jneurosci.org as supplemental material). The same effects on p53 activity, promoter transactivation, and mRNA levels (supplemental Fig. 2A,C, available at www.jneurosci.org as supplemental material) were observed in cells expressing PS2 harboring the N141I FAD mutation.

\section{PS1 influences p53 expression and activity and modulates PS2 expression}

Unlike PS2, PS1 appeared either to be inert in nonstimulated conditions or to decrease neuronal susceptibility to various apoptotic stimuli (Bursztajn et al., 1998). Interestingly, PS1 overexpression decreased p53 activity, expression, and promoter transactivation (supplemental Fig. $3 A, B$, available at www. jneurosci.org as supplemental material), whereas PS1 deletion led to an opposite phenotype (supplemental Fig. $3 C, D$, available at www.jneurosci.org as supplemental material). The distinct control of p53 by these proteins led us to examine whether there could be a functional cross talk between the two parent presenilins for this paradigm. In support of such an hypothesis, we previously demonstrated that PS2 overexpression drastically reduced the levels of both overexpressed and endogenous PS1 (Alves da Costa et al., 2002). Here we show that PS1 depletion
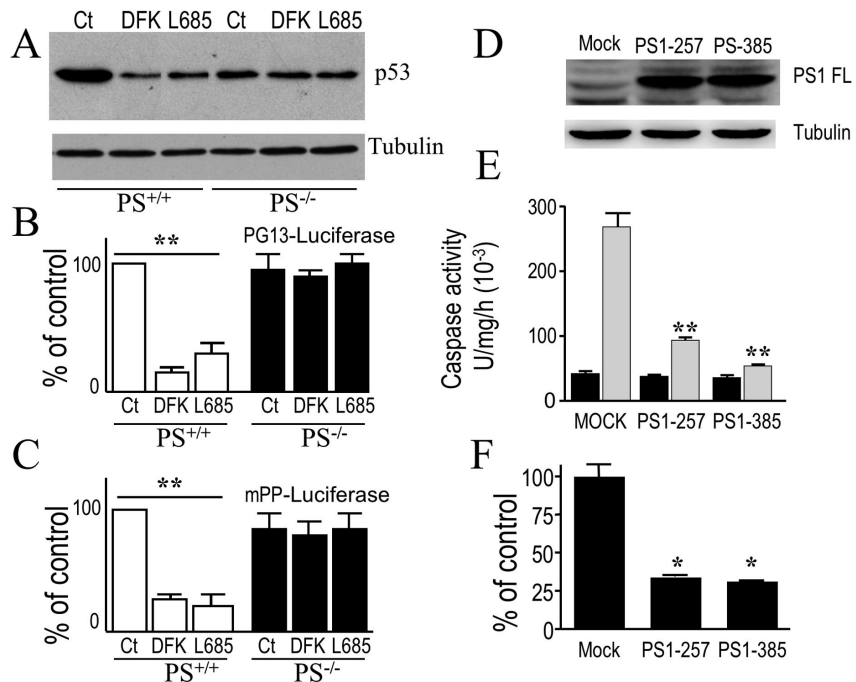

Figure 2. Effect of $\gamma$-secretase inhibitors on p53. PS ${ }^{+/+}$and PS ${ }^{-/-}$fibroblasts were transiently transfected with PG13-luciferase or mPP-luciferase vectors as described in Materials and Methods. $A-C$, At $24 \mathrm{~h}$ after transfection, the cells were treated for $24 \mathrm{~h}$ without (Ct) or with the indicated $\gamma$-secretase inhibitor (DFK167, $50 \mu \mathrm{m}$; L685, $2 \mu \mathrm{M}$ ); then p53 expression in nuclear extracts $(\boldsymbol{A})$, p53 transcriptional activity $(\boldsymbol{B})$, and transactivation of $\mathrm{MPP}(\boldsymbol{C})$ were measured as described in Materials and Methods. Bars correspond to the ratios of luciferase/ $\beta$ galactosidase activities expressed as a percentage of control activities monitored in $\mathrm{PS}^{+/+}$and are the means \pm SEM of three independent determinations. $\boldsymbol{D}-\boldsymbol{F}$, Stably transfected TSM1 neuronal cells overexpressing Asp ${ }^{257}$ Ala-PS1 (PS1-257) or Asp ${ }^{385}$ Ala-PS1 (PS1-385) were assayed for their susceptibility to staurosporine-induced caspase 3 activation $(\boldsymbol{E})$ and were analyzed for their p53 mRNA levels by real-time PCR $(\boldsymbol{F})$ as described in Materials and Methods. Bars in $\boldsymbol{E}$ and $\boldsymbol{F}$ are the means \pm SEM of nine and three independent experiments, respectively, performed in duplicate $(\boldsymbol{E})$ or triplicate $(\boldsymbol{F}){ }^{*} p<0.01 ;{ }^{* *} p<0.001$.

drastically increased PS2-like immunoreactivity (supplemental Fig. $4 A, C$, available at www.jneurosci.org as supplemental material); conversely, PS1 overexpression significantly decreased PS2 expression (supplemental Fig. 4B,C, available at www.jneurosci.org as supplemental material).

Mutations of catalytic aspartyl residues of PS and $\gamma$-secretase inhibitors lower $\mathrm{p} 53$ expression and activity in wild-type, but not in PS-deficient, fibroblasts

In agreement with analyses in PS-deficient cells, the administration of Rac-Val-Ile[(S)-4-amino-2,2-difluoro-3-oxo-pentanoyl]-ValIle-o-methyl (DFK167) and \{1S-benzyl-4R [1-[1-S-carbamoyl-2phenethylcarbamoyl)-1S-3-methylbutylcarbamoyl]-2R-hydroxy5-phenylpentyl\}carbamic acid tert-butyl ester (L685458), two potent inhibitors of $\gamma$-secretase activity (Wolfe, 2001), drastically reduced $\mathrm{p} 53$ protein expression (Fig. $2 A$ ), p 53 functional activity (Fig. $2 B$ ), and transactivation of the p53 promoter (Fig. $2 C$ ). Significantly, these inhibitors were totally ineffective in PSdeficient fibroblasts (Fig. 2A-C). The sensitivity of p53 to both PS deficiency and $\gamma$-secretase inhibition suggested that the endogenous product controlling p53 transcription in wild-type fibroblasts was likely to be generated via a PS-dependent $\gamma$-secretase activity. To support this hypothesis further, we established stable transfectants expressing mutated PS1 in which the residues of aspartyls 257 or 385 had been replaced by aliphatic amino acids (Fig. 2D). It had been shown previously that these mutated proteins, when overexpressed, substituted for endogenous PSs and inhibited the $\gamma$-secretase-mediated cleavages of $\beta$ APP and Notch. In agreement with the above data, both mutated PS1s drastically diminished the staurosporine-induced caspase 3 activation in HEK 293 cells (Fig. 2E). This was accompanied by a 
drastic reduction of p53 mRNA levels measured by real-time PCR (Fig. $2 F$ ).

The $\gamma$-secretase-derived C-terminal fragments of $\beta$ APP control p53 at a transcriptional level

The "canonical" $\gamma$-secretase-mediated cleavage of $\beta$ APP leads to the formation of $\mathrm{A} \beta_{40}$ and a 59-amino-acid-long fragment called AICDC59 (Passer et al., 2000). It has been demonstrated recently that $\beta$ APP also undergoes an additional cleavage $(\varepsilon-$ cleavage) slightly downstream of the " $\gamma$-site," liberating a shorter 50 -aminoacid-long peptide (AICDC50) (Gu et al., 2001; Sastre et al., 2001). We therefore examined whether AICDC50 and AICDC59 overexpression could modulate p53 in wild-type and PS-deficient murine blastocysts as well as in HEK 293 cells. AICD overexpression increased both $\mathrm{p} 53$ activity and transactivation of murine and human p53 promoters in wild-type blastocysts (Fig. 3A, B, BD6), PS-deficient blastocysts (Fig. 3A, B, BD8), and HEK 293 cells (Fig. $3 C, D)$. Accordingly, real-time PCR analysis showed that both AICDC50 and AICDC59 significantly induced p53 mRNA levels in HEK 293 cells (Fig. 3E). To rule out a possible influence of AICD on p53 mRNA stability, we treated mock- and AICDC59-transfected HEK 293 cells with actinomycin D to block neo transcription; then we estimated p 53 mRNA levels by real-time PCR. Figure $3 G$ confirms that AICDC59-expressing cells display higher p53 mRNA levels at each kinetics time, but p53 mRNA levels decrease with similar slopes (29.85 vs 29.69 ) in both cell lines, indicating that AICDC59 does not exert its effect on p53 mRNA by affecting its cellular stability. Indeed, AICDC59 clearly transactivates $\mathrm{p} 53$ promoter and increases p53 mRNA levels by physically interacting with the $\mathrm{p} 53$ promoter, as demonstrated by gel shift assays (Fig. $3 F$ ).

\section{AICDC59 triggers p53-dependent caspase 3 activation}

p53 is a tumor suppressor gene that exerts its pro-apoptotic signaling via complex cellular pathways (Fisher, 2001). It has been established previously that p53induced neuronal apoptosis clearly was associated with the activation of caspase 3 (Cregan et al., 1999). We therefore hypothesized that caspase 3 activation could be used as a read-out of the function of AICD in the cellular control of p53. This hypothesis was confirmed by the observation that AICDC59 cDNA transfection (Fig. 4A) led to a statistically significant increase in staurosporine-stimulated
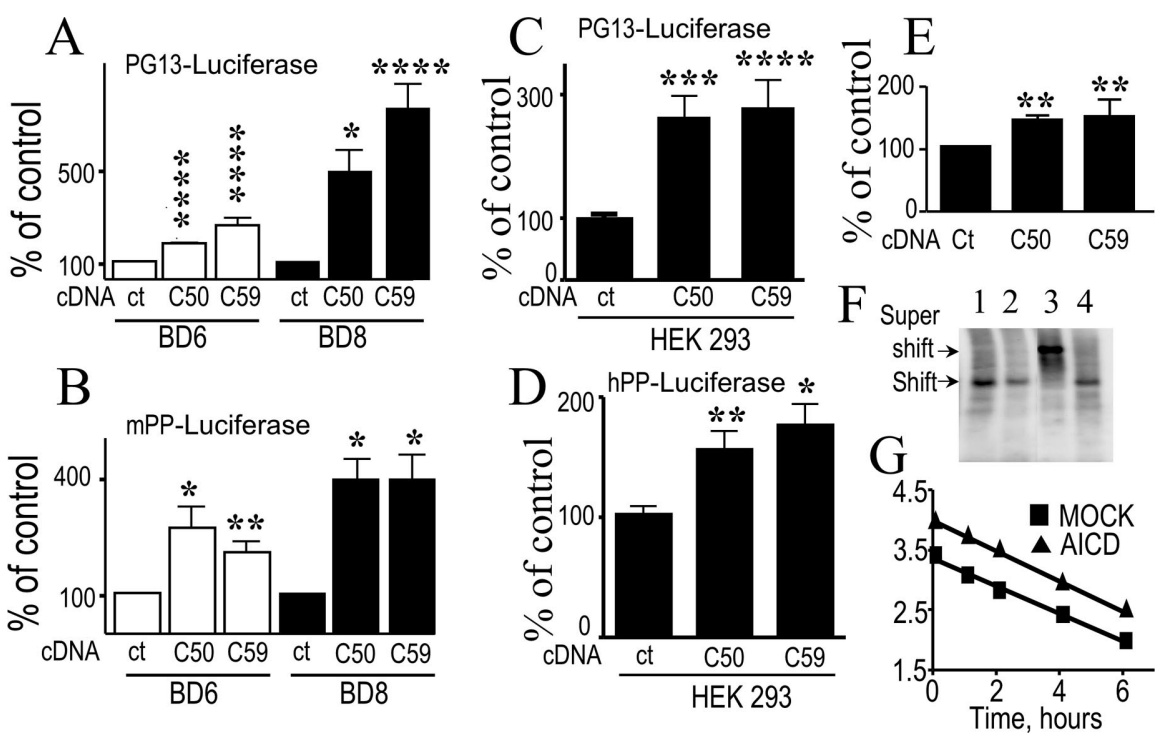

Figure 3. AICDC50 and AICDC59 modulate p53. $\boldsymbol{A}-\boldsymbol{D}, \mathrm{BD} 6$ and BD8 blastocysts $(\boldsymbol{A}, \boldsymbol{B})$ or HEK 293 cells $(\boldsymbol{C}, \boldsymbol{D})$ were transiently transfected with PG13-luciferase $(\boldsymbol{A}, \boldsymbol{C})$, mPP-luciferase $(\boldsymbol{B})$, or hPP-luciferase $(\boldsymbol{D})$ vectors together with an empty vector $(\boldsymbol{C t})$, AICDC50 (C50), or AICDC59 (C59) CDNAs as described in Materials and Methods. At $48 \mathrm{~h}$ after transfection, the p53 transcriptional activity $(\boldsymbol{A}, \boldsymbol{C})$ or transactivation of $\operatorname{mPP}(\boldsymbol{B}) \operatorname{orhPP}(\boldsymbol{D})$ was measured as detailed in Materials and Methods. Bars correspond to the ratios of luciferase/ $\beta$-galactosidase activities expressed as a percentage of control activities (taken as 100) in corresponding cells transfected with empty vector and are the means \pm SEM of 12-18 independent determinations. $\boldsymbol{E}$, HEK 293 cells were transiently transfected with empty vector (Ct), AICDC50 (C50), or AICDC59 (C59) CDNA; then p53 mRNA levels were analyzed $48 \mathrm{~h}$ after transfection by real-time PCR as described in Materials and Methods. Bars correspond to p53 mRNA density expressed as a percentage of control mock-transfected cells (taken as 100) and are the means \pm SEM of three independent experiments. ${ }^{*} p<$ $0.05 ;{ }^{* *} p<0.01 ;{ }^{* * *} p<0.005 ;{ }^{* * * *} p<0.001$. F, Gel shift analysis obtained after transient cotransfection of HEK 293 cells with AICDC59, Tip60, and Fe65 CDNAs as described in Materials and Methods. Lane 1, ${ }^{32}$ P-labeled p53-2 oligo retarded by AICD59enriched nuclear extracts; lane 2, ${ }^{32}$ P-labeled p53-2 probe in competition with cold p53-2 probe; lane 3, supershift of the ${ }^{32} \mathrm{P}$-labeled p53-2 probe by anti-myc antibodies; lane 4, supershift of the ${ }^{32} \mathrm{P}$-labeled p53-2 probe with control nonspecific anti-mouse antibody. $\mathbf{G}$, The kinetics of $\mathrm{p} 53$ mRNA level decreases in actinomycin D-treated mock- and AICDC59-transfected HEK 293 cells. At $33 \mathrm{~h}$ after transfection the cells were treated for the indicated times with $10 \mu \mathrm{g} / \mathrm{ml}$ of actinomycin D; then p53 mRNA levels were estimated by real-time PCR as described in Materials and Methods.
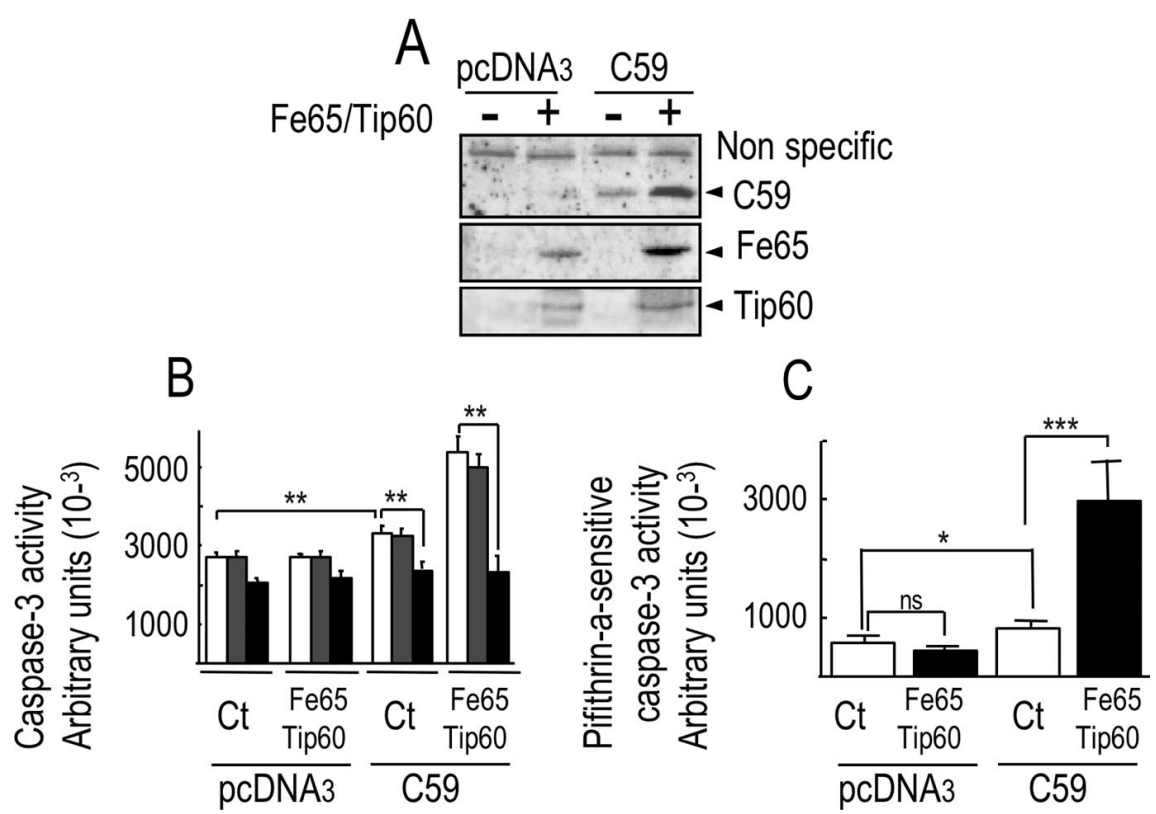

Figure 4. AICDC59 increases caspase 3 activity in a p53-dependent manner. Wild-type fibroblasts were transfected with pCDNA3 or AICDC59 coding vectors cotransfected or not (Ct) with Tip60 and Fe65 CDNA. A, AICD, Fe65, and Tip60 immunoreactivities were analyzed as described in Materials and Methods. $\boldsymbol{B}$, Caspase 3 activity was measured after stimulation with staurosporine (see Materials and Methods). Cells were treated with pifithrin- $\alpha$ (black bars) or a pifithrin- $\alpha$-inactive analog (gray bars) or were not treated (white bars). C, Pifithrin- $\alpha$-sensitive p53-dependent caspase 3 activation was determined by the difference between the caspase 3 activities measured in the absence and in the presence of the inhibitor. Bars in $\boldsymbol{B}$ and $\boldsymbol{C}$ are the means \pm SEM of three to six independent determinations. ${ }^{*} p<0.05 ;{ }^{* *} p<0.01$; ${ }^{* * *} p<0.001$; ns, not significant. 
caspase 3 activity in fibroblasts (Fig. $4 B$ ). This increase was abolished by the p53 inhibitor, pifithrin- $\alpha$, but not by one of its inactive analogs (Fig. 4B). To enhance AICDC59-associated phenotype, we took advantage of recent studies showing that Fe65 could stabilize AICDs (Kimberly et al., 2001; Kinoshita et al., 2002b). Furthermore, Tip60, together with Fe65, was reported to favor AICD translocation into the nucleus where the protein could act as a transcription factor (Cao and Südhof, 2001). Clearly, AICDC59, Fe65, and Tip60 cDNA cotransfection enhanced AICDC59 immunoreactivity in fibroblasts (Fig. 4A). Interestingly, this increase was associated with a drastic increase in total (Fig. $4 B$ ) and pifithrin- $\alpha$-sensitive (Fig. $4 C$ ) caspase 3 activity. These data additionally emphasize our observation of an AICDassociated control of p53 and indicate that AICD-induced p53 modulation has direct repercussions on the levels of the caspase 3 activity.

\section{AICDC59 triggers cell death that is abolished by p53 deficiency}

We next attempted to examine whether increased caspase 3 activation indeed was linked to apoptotic stigmata and, if so, whether AICD-induced caspase 3 activation and associated cell death both could be abolished by p53 deficiency. We took advantage of recent p19 ${ }^{\text {Arf-I- }}$ (Kamijo et al., 1997) and p19 ${ }^{\text {Arf-I- }}$ p53 $3^{-1-}$ (Weber et al., 2000) cell systems designed to study the influence of p53 deficiency. First we showed that p19 Arf-/- -deficient cells still respond to staurosporine by activating caspase 3 and that this phenotype is reduced by additional p53 depletion (data not shown). Interestingly, we confirmed that PS2 and N141I-PS2induced caspase 3 activation was strictly dependent on $\mathrm{p} 53$. Thus both proteins increased caspase 3 activity in p19 ${ }^{\text {Arf- }}$ - fibroblasts, whereas they were fully inactive in $\mathrm{p} 19^{\mathrm{Arf}-1-} \mathrm{p} 53^{-1-} \mathrm{fi}-$ broblasts (supplemental Fig. 2D,E, available at www.jneurosci. org as supplemental material). AICDC59 transfection, together with Fe65 and Tip60, drastically enhanced pifithrin- $\alpha$-sensitive caspase 3 activity, although this phenotype was not observed in Arf $^{-1-}$ p53 $3^{-1-}$ fibroblasts (supplemental Fig. $5 A, B$, available at www.jneurosci.org as supplemental material). Of most interest, we showed that AICDC59 transfection increased the number of terminal deoxynucleotidyl transferase-mediated biotinylated UTP nick end labeling-positive (TUNEL-positive) cells in p19 Arf-/- cells, which was increased additionally by Fe65 and Tip60 (supplemental Fig. 5C,E, available at www.jneurosci.org as supplemental material). However, the lack of p53 fully abolished the AICDC59 and AICDC59/Tip60/Fe65-induced cell death (supplemental Fig. 5D,E, available at www.jneurosci.org as supplemental material). These data agree well with previous studies indicating that the $\gamma$-secretase-generated C-terminal fragments of $\beta$ APP could induce apoptosis (Passer et al., 2000) and that this phenotype was linked to Tip60 in human neuroglioma H4 cells (Passer et al., 2000; Kinoshita et al., 2002a). They additionally support the fact that this process occurs via the control of p53 transcription.

\section{$\beta A P P$ and amyloid precursor protein-like protein 2 deficiencies affect $\mathrm{p} 53$ in vitro and in vivo}

PS-dependent $\gamma$-secretase activity is required for the intramembranous cleavage of several proteins (Sisodia and St. GeorgeHyslop, 2002). To demonstrate that the endogenous $\gamma$-secretasePS-dependent products that modulate 53 are indeed the $\beta$ APPderived AICDs, we examined the status of p53 in $\beta \mathrm{APP}^{-/-}$ fibroblasts. The absence of $\beta$ APP reduced p 53 functional activity, transactivation of the murine p53 promoter construct, p53
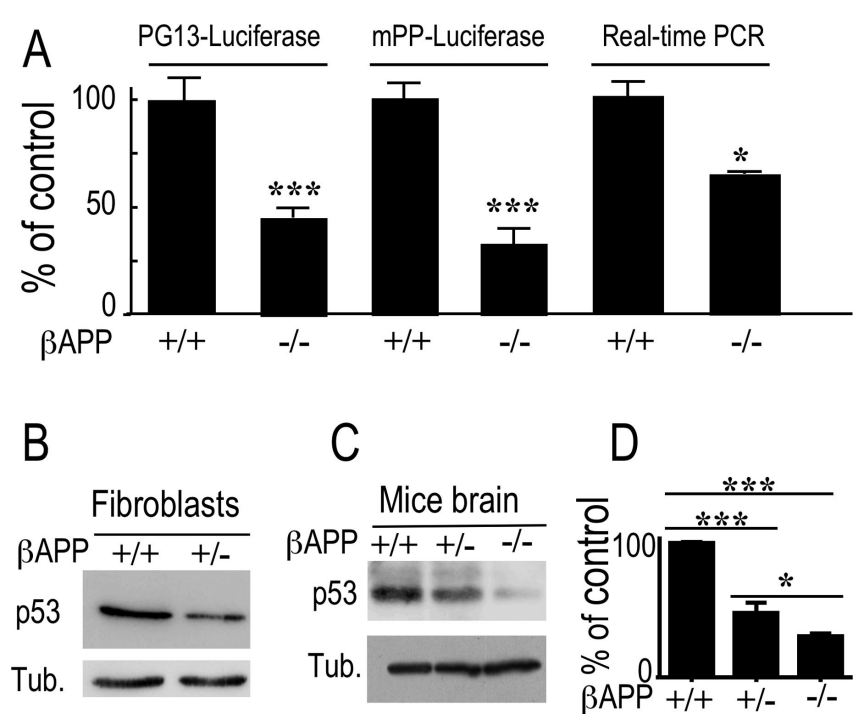

Figure 5. Influence of $\beta$ APP depletion on p53 in vitro and in vivo. $\boldsymbol{A}, \mathrm{p} 53$ transcriptional activity, transactivation of murine p53 promoter, and p53 mRNA levels were measured as described in Materials and Methods in wild-type $\beta A P P(+/+)$ or $\beta A P P-d e f i c i e n t ~(-/-)$ fibroblasts. Bars for PG13- and mPP-luciferase activities correspond to the ratios of luciferase $/ \beta$ galactosidase activities expressed as a percentage of control activities monitored in $\beta$ APP $+1+$ and are the means \pm SEM of six independent determinations. Bars corresponding to real-time $P C R$ analysis of $p 53$ mRNA are the means \pm SEM of four independent determinations. p53-like immunoreactivity in the indicated cell lines $(\boldsymbol{B})$ or in extracts from the indicated mice brain $(\boldsymbol{C})$ was measured as described in Materials and Methods. Bars in $\boldsymbol{D}$ correspond to densitometric analyses of $p 53$ in the indicated mice brain and are the means \pm SEM of three independent determinations. ${ }^{*} p<0.05 ;{ }^{* * *} p<0.001$.

mRNA levels measured by real-time PCR (Fig. $5 A$ ), and p53 protein expression ( $45 \pm 4.3 \%$ of reduction; $n=6$; $p<0.001$ ) (Fig. $5 B$ ). Interestingly, 553 protein expression also was affected in a gene dose-dependent manner in vivo. Thus p53 immunoreactivity was lower in $\beta \mathrm{APP}^{+/-}$mice brain than in control $\beta \mathrm{APP}^{+/+}$ mice, a phenotype additionally accentuated in $\beta \mathrm{APP}^{-1-}$ mice brain (Fig. $5 C, D$ ). These data indicate that at least some of the endogenous fragments generated by PS-dependent $\gamma$-secretase that modulate p53 were AICDs. Clearly, however, the depletion of $\beta$ APP did not achieve full downregulation of $\mathrm{p} 53$ expression and activity. It should be noted here that fibroblasts do not express amyloid precursor protein-like protein 1 (APLP1; data not shown). In this context we therefore examined the possibility that APLP2, a $\beta$ APP homolog protein that also undergoes $\gamma$-secretase cleavage (Eggert et al., 2004) leading to biologically active intracellular C-terminal domain (Scheinfeld et al., 2002; Walsh et al., 2003; Pardossi-Piquard et al., 2005), could participate in the control of p53. Indeed, in fibroblasts the APLP2 knock-out led to reduced p53 expression (Fig. $6 A, B$ ), activity (Fig. 6C), promoter transactivation (Fig. 6D), and mRNA levels (Fig. 6E). None of these paradigms appeared to be potentiated additionally by double $\beta$ APP/APLP2 deficiency (Fig. $6 A-E$ ).

p53 is potentiated by PS1 mutations in HEK 293 cells and is increased in sporadic $\mathrm{AD}$ and FAD-affected human brains

The above data predict that PS1 mutations associated with familial AD cases, which affect $\gamma$-secretase activity, also should modulate AICD and thereby $\mathrm{p} 53$ expression in FAD-affected brains. To address this point, we first examined whether PS1 mutations alter p53 activity in cells. Transient cotransfections of PG13 reporter gene, together with PS1 cDNAs harboring a series of clinical missense mutations or deletion ( $\triangle$ E9PS1) (Perez-Tur et al., 1995), 
led to significantly increased p53 activity (Fig. 7A). These data were corroborated by immunohistochemical analysis of p53 immunoreactivity in the same FAD cases. Figure $7 B$ shows the typical labeling of endogenous p53 in control (Fig. $7 B$, top panels) and FAD-affected (Fig. $7 B$, bottom panels) temporal cortices. In nondemented cases the p53 immunoreactivity was diffuse in neuropil and cell bodies of a few neurons, whereas the p53 staining of neuronal cell bodies was consistently much more intense and the number of positive neurons was drastically higher in FAD cases (Fig. $7 B, C$ ). Cell nuclei, central cores of senile plaques, immature lesions (diffuse plaques), and neurofibrillary tangles were not labeled. Close quantification of p53-positive neurons indicated a higher number of positive neurons in FAD brains than in unaffected brains (Fig. 7C). In agreement with these in situ experiments, p53 immunoreactivity was increased in extracts from three different FAD brains harboring PS1 mutations (Fig. $7 D$ ). These data indicated that neuronal p53 expression was higher in FAD than in nondemented brains at both immunohistochemical and biochemical levels.

However, it should be noted that p53 immunoreactivity and the number of p53-positive neurons were also higher in sporadic $\mathrm{AD}$ than in nondemented brains (Fig. $7 C, D$ ). Because it usually is accepted that the increase of $\mathrm{A} \beta$ in sporadic $\mathrm{AD}$ is not linked to an enhanced $\gamma$-secretase activity but rather to post-transcriptional modifications, we examined the status of insulin-degrading enzyme (IDE), the protease thought to catabolize AICD (Edbauer et al., 2002). Indeed, we found that in sporadic AD brains, IDE was reduced significantly (Fig. $7 E$ ), thereby suggesting a possible higher catabolic stability of AICD in sporadic brains and thereby contributing to enhanced p53 expression. It is noteworthy that IDE levels in FAD brains were not affected (Fig. 7E).

\section{Discussion}

The PS-dependent $\gamma$-secretase is borne by a high-molecular-weight complex composed of at least four distinct proteins, i.e., PS1 or PS2, nicastrin, Aph-1, and Pen-2 (Herreman et al., 2000; Yu et al., 2000; Zhang et al., 2000; Francis et al., 2002; Goutte et al., 2002). Because there are two different PSs (PS1 and PS2), three murine Aph-1 homologs (Aph-1a, Aph-1b, and Aph-1c) (Steiner et al., 2002; Luo et al., 2003; Ma et al., 2005), and even two splice isoforms of Aph-1a (Aph-1aL and Aph1aS) (Steiner et al., 2002; Gu et al., 2003; Luo et al., 2003), several types of complexes harboring distinct combinations of the above proteins could be postulated. Indeed, this was demonstrated by Shirotani and colleagues, who characterized various complexes with specific composition (Heber et al., 2000; Shirotani et al., 2004). Some lines of evidence indicate that these physical differences could underlie distinct biological activities (Hong et al., 1999; Chen et al., 2003; Gu et al., 2004; Kang et al., 2005).

It previously had been documented that PS1 and PS2 also modulated cell death differently. Thus PS1 decreased neuronal compared with controls.

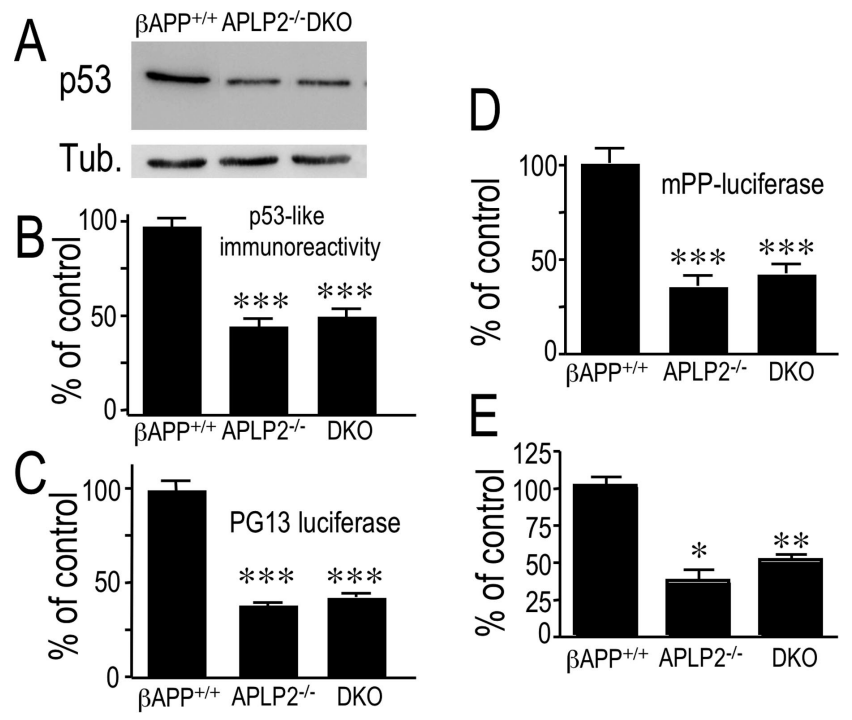

Figure 6. Influence of APLP2 depletion on p53. p53 immunoreactivity $(\boldsymbol{A}, \boldsymbol{B}), \mathrm{p} 53$ activity $(\boldsymbol{C})$, transactivation of murine p53 promoter $(\boldsymbol{D})$, and mRNA levels $(\boldsymbol{E})$ were measured as described in Materials and Methods in wild-type $\left(\beta \mathrm{APP}^{+/+}\right)$, APLP2-deficient (APLP2 $\left.{ }^{-/-}\right)$, or double $\beta$ APP/APLP2-deficient (DK0) fibroblasts. Note that fibroblasts do not express APLP1 (data not shown). Bars in $\boldsymbol{B}-\boldsymbol{D}$ correspond to the densitometric analysis of p53 immunoreactivity $(\boldsymbol{B})$ or to the ratios of luciferase/ $\beta$-galactosidase activities $(\boldsymbol{C}, \boldsymbol{D})$ expressed as a percentage of control monitored in $\beta \mathrm{APP}^{+/+}$and are the means \pm SEM of six independent determinations. Bars in $\boldsymbol{E}$ correspond to the mRNA levels measured by real-time $P C R$, are expressed as a percentage of mRNA levels in $\beta$ APP $+/+$ fibroblasts, and are the means \pm SEM of four experiments. ${ }^{*} p<0.01 ;{ }^{* *} p<0.005,{ }^{* * *} p<0.001$
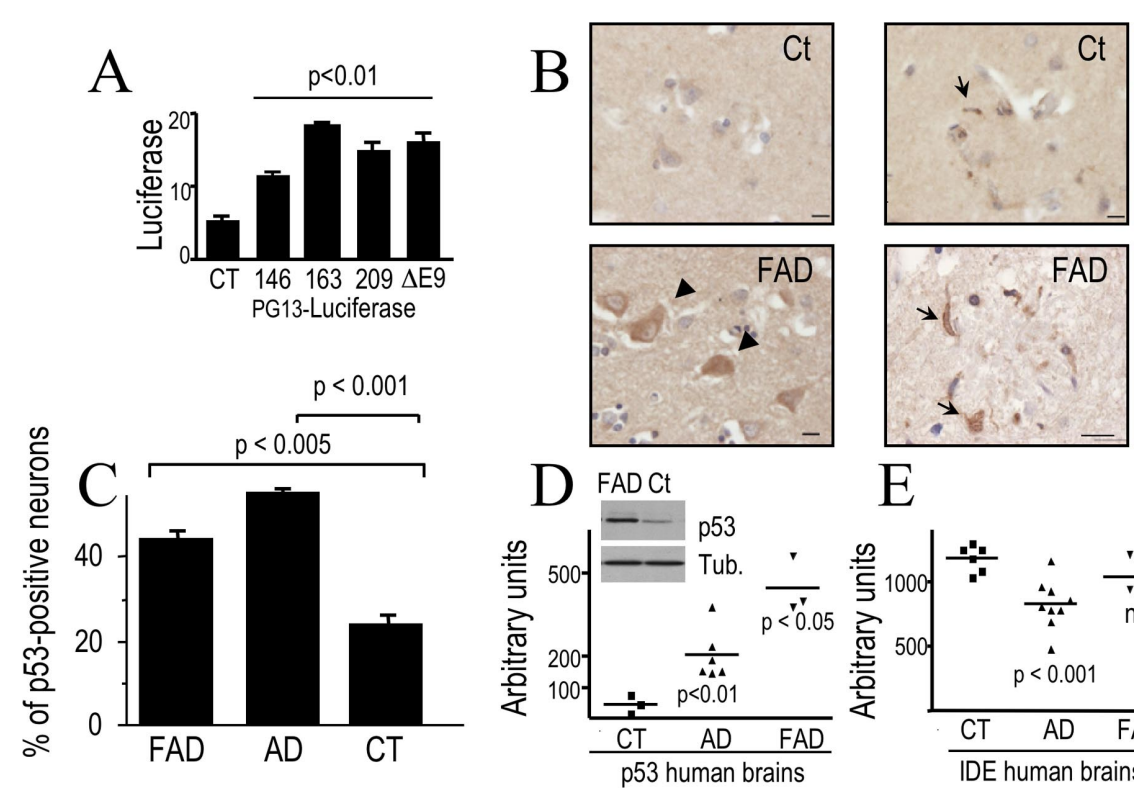

Figure 7. Influence of PS1 mutations on p53 expression in FAD-affected human brains. $A, p 53$ transcriptional activity after transient transfection of HEK 293 cells with empty CDNA (Ct) or PS1 CDNA harboring the M146V, (146), H163R (163), G209V (209), or PS1 2 E9 ( $\Delta$ E9) mutations and deletion. Bars correspond to the ratios of luciferase/ $\beta$-galactosidase activities expressed as a percentage of control activities in cells transfected with empty vector and are the means \pm SEM of three independent determinations. $B, p 53$ immunohistochemistry in temporal cortex of control subjects (Ct, top panels) and FAD cases (bottom panels; see cases in Materials and Methods). Note very few neuronal labels in control case (top left panel), with a faint label in microglial cells (arrow in top right panel), p53 immunolabeling in the cytoplasm of neurons in FAD (arrowheads in bottom left panel), and p53-like immunoreactivity associated with cotton wool plaque in FAD (arrows in bottom right panel). Scale bars, $20 \mu \mathrm{m}$. C, The bars correspond to the number of p53-positive neurons in controls, sporadic AD, and FAD brains (see Materials and Methods) and are the means \pm SEM. $\boldsymbol{D}$, Values correspond to the densitometric analysis of p53-like immunoreactivity in controls, sporadic AD, and FAD brains (see Materials and Methods). Inset represents a typical Western blot analysis comparing p53-like immunoreactivity in control (Ct) and FAD brain. $\boldsymbol{E}$, Values correspond to the densitometric analysis of IDE-like immunoreactivity measured as detailed in Materials and Methods in controls, sporadic AD, and FAD brains. ns, Not statistically significant when 
susceptibility to apoptosis (Bursztajn et al., 1998); conversely, cell death appeared to be enhanced in antisense PS1-expressing cells, a phenotype that could be rescued by overexpression of the antiapoptotic oncogene Bcl-2 (Hong et al., 1999). Unlike PS1, PS2 displays a clear pro-apoptotic phenotype (Wolozin et al., 1996; Araki et al., 2000; Alves da Costa et al., 2002, 2003) that previously was shown to be mediated via p53-dependent pathways (Alves da Costa et al., 2002). Our data here clearly confirm the opposite functions of the two parent proteins and indicate that both phenotypes were associated with a modulation of p53 expression, p53 activity, and transcriptional activation of the p53 promoter (supplemental Figs. 1, 3, available at www.jneurosci.org as supplemental material). Our study also establishes a possible cross talk between the two presenilins. Thus we previously demonstrated that overexpression of either wild-type or mutated PS2 lowered the levels of PS1-like immunoreactivity in HEK 293 cells (Alves da Costa et al., 2002). Here we show that PS1 depletion or overexpression drastically increases or reduces PS2 expression, respectively (supplemental Fig. 4, available at www.jneurosci.org as supplemental material), in agreement with a recent study showing that mutated PS1 drastically reduced PS2 fragments (Kang et al., 2005). Because it has been shown that p53 acted as a repressor of the transcription of the human PS1 gene (Pastorcic and Das, 2000) in agreement with a previous study demonstrating the inhibition of PS1 expression promoted by p53 (Roperch et al., 1998), we can postulate reasonably that PS2-mediated increase in p53 concomitantly leads to reduced PS1 expression. This intimate cross talk between PS1 and PS2 ultimately could control the levels of the $\gamma$-secretase-mediated AICD formation.

Most importantly, our study demonstrates the transcriptional control of p53 by AICD, the PS-dependent $\gamma$-secretase cleavage product of $\beta \mathrm{APP}$, and clearly suggests that FAD mutations, which increase $\gamma$-secretase cleavage (Marambaud et al., 1998) and therefore AICD production, lead to enhanced p53 expression and likely increase susceptibility to subsequent apoptotic cell death in FAD cases of $\mathrm{AD}$. This agrees well with a study showing that presenilin 1 mutations increased cell vulnerability to DNA damage, a cellular traumatism generally associated with p53enhanced production (Chan et al., 2002).

The correlation among p53 overexpression, neuronal DNA damage, and apoptosis (Bar et al., 2004) raises the question as to whether AICD-regulated changes in p53 expression also could contribute to neuronal death in sporadic AD. In these AD cases it generally is thought that neuropathological lesions arise from postproduction changes in $\gamma$-secretase products, e.g., the fibrillization of $\mathrm{A} \beta$ or reduced catabolism of $\mathrm{A} \beta$ and AICD. In this context it is noteworthy that the activity of IDE, the enzyme that apparently catabolizes both $\mathrm{A} \beta$ and AICD (Edbauer et al., 2002), is reduced in brain tissue from late-onset sporadic cases of $\mathrm{AD}$ (Perez et al., 2000). It is therefore possible that reduced IDE could increase cellular AICD levels and contribute to enhanced AICDmediated p53 expression in sporadic AD.

Together, our data demonstrate both a new function for PSdependent $\gamma$-secretase-associated AICD and an unexpected mechanism for regulating p53 expression. Our data have another implication for $\mathrm{AD}$ therapeutics. The strategy aimed at specifically inhibiting $\gamma$-secretase faces major theoretical problems. Thus preventing $\gamma$-secretase cleavage would affect the physiology of several proteins, the functions of which are linked closely to their intramembranous proteolytic processing by $\gamma$-secretase ( $\mathrm{Si}$ sodia and St. George-Hyslop, 2002). Furthermore, we recently demonstrated that blockade of PS-dependent $\gamma$-secretase could lead to decreased activity of neprilysin, a major $\mathrm{A} \beta$-degrading enzyme, thereby enhancing the concentration of $\mathrm{A} \beta$ peptide (Pardossi-Piquard et al., 2005, 2006). The present report additionally suggests that chronic treatment with $\gamma$-secretase inhibitors could affect p53 drastically and, potentially therefore, ultimately lead to tumorigenicity. In this context it is noteworthy that an APP-dependent complex including Fe65 and Tip60 also regulates the transcription of another tumor suppressor, namely KAI1/CD82 (Baek et al., 2002). This concern is supported additionally by the observation that PS deficiency leads to malignant keratocarcinoma in mice (Tournoy et al., 2004) and that the severity of the skin lesions, from benign keratosis to carcinomas, appears to be linked directly to the extent of PS deficiency (Xia et al., 2001; Tournoy et al., 2004). It remains to be proven that these skin tumors arise specifically via loss of PS-dependent regulation of p53 per se. Nevertheless, our results emphasize the need for careful examination of p53-related side effects when assessing the potential of $\gamma$-secretase inhibitors as long-term treatments or prophylactic therapies in $\mathrm{AD}$.

\section{References}

Alves da Costa C, Paitel E, Mattson MP, Amson R, Telerman A, Ancolio K, Checler F (2002) Wild-type and mutated presenilin-2 trigger p53dependent apoptosis and down-regulate presenilin-1 expression in HEK 293 human cells and in murine neurons. Proc Natl Acad Sci USA 99:4043-4048.

Alves da Costa C, Mattson M, Ancolio K, Checler F (2003) The C-terminal fragment of presenilin 2 triggers p53-mediated staurosporine-induced apoptosis, a function independent of the presenilinase-derived N-terminal counterpart. J Biol Chem 278:12064-12069.

Araki W, Yuasa K, Takeda S, Shirotani K, Takahashi K, Tabira T (2000) Overexpression of presenilin-2 enhances apoptotic death of cultured cortical neurons. Ann NY Acad Sci 920:241-244.

Araki W, Yuasa K, Takeda S, Takeda K, Shirotani K, Takahashi K, Tabira T (2001) Pro-apoptotic effect of presenilin 2 (PS2) overexpression is associated with down-regulation of $B c l-2$ in cultured neurons. J Neurochem 79:1161-1168.

Baek SH, Ohgi KA, Rose DW, Koo EH, Glass CK, Rosenfeld MG (2002) Exchange of N-CoR corepressor and Tip60 coactivator complexes links gene expression by NF- $\kappa \mathrm{B}$ and $\beta$-amyloid precursor protein. Cell 110:55-67.

Bar J, Cohen-Noyman E, Geiger B, Oren M (2004) Attenuation of the p53 response to DNA damage by high cell density. Oncogene 23:2128-2137.

Bursztajn S, DeSouza R, McPhie DL, Berman SA, Shioi J, Robakis NK, Neve RL (1998) Overexpression in neurons of human presenilin-1 or a presenilin-1 familial Alzheimer's disease mutant does not enhance apoptosis. J Neurosci 18:9790-9799.

Cao X, Südhof TC (2001) A transcriptively active complex of APP with Fe65 and histone acetyltransferase Tip60. Science 293:115-120.

Chan SL, Culmsee C, Haughey N, Klapper W, Mattson MP (2002) Presenilin-1 mutations sensitize neurons to DNA damage-induced death by a mechanism involving perturbed calcium homeostasis and activation of calpains and caspase 12. Neurobiol Dis 11:2-19.

Checler F (1995) Processing of the $\beta$-amyloid precursor protein and its regulation in Alzheimer's disease. J Neurochem 65:1431-1444.

Checler F (1999) Presenilins: multifunctional proteins involved in Alzheimer's disease pathology. IUBMB Life 48:33-39.

Chen F, Tandon A, Sanjo N, Gu YJ, Hasegawa H, Arawaka S, Lee FJS, Ruan X, Mastrangelo P, Erdebil S, Wang L, Westaway D, Mount HTJ, Yankner B, Fraser PE, St. George-Hyslop P (2003) Presenilin 1 and presenilin 2 have different effects on the stability and maturation of nicastrin in mammalian cells. J Biol Chem 278:19974-19979.

Cregan SP, MacLaurin JG, Craig CG, Robertson GS, Nicholson DW, Park DS, Slack RS (1999) Bax-dependent caspase-3 activation is a key determinant in p53-induced apoptosis in neurons. J Neurosci 19:7860-7869.

de la Monte S, Sohn YK, Wands JR (1997) Correlates of p53- and Fas (CD95)-mediated apoptosis in Alzheimer's disease. J Neurol Sci 152:73-83.

De Strooper B (2003) Aph-1, Pen-2, and nicastrin with presenilin generate an active $\gamma$-secretase complex. Neuron 38:9-12.

Edbauer D, Willem M, Lammich S, Steiner H, Haass C (2002) Insulin- 
degrading enzyme rapidly removes the $\beta$-amyloid precursor protein intracellular domain (AICD). J Biol Chem 277:13389-13393.

Eggert S, Paliga K, Soba P, Evin G, Masters CL, Weidemann A, Beyreuther K (2004) The proteolytic processing of the amyloid precursor protein gene family members APLP- 1 and APLP- 2 involves $\alpha$-, $\beta$-, $\gamma$-, and $\varepsilon$-like cleavages. Modulation of APLP-1 processing by $N$-glycosylation. J Biol Chem 279:18146-18156.

El-Deiry W, Kern S, Pietenpol J, Kinzler K, Vogelstein B (1992) Definition of a consensus binding site for p53. Nat Genet 1:45-49.

Fisher DE (2001) The p53 tumor suppressor: critical regulator of life and death in cancer. Apoptosis 6:7-15.

Francis R, McGrath G, Zhang J, Ruddy DA, Sym M, Apfeld J, Nicoli M, Maxwell M, Hai B, Ellis MC, Parks AL, Xu W, Li H, Gurney M, Myers RL, Himes CS, Hiebsch R, Ruble C, Nye JS, Curtis D (2002) Aph-1 and Pen-2 are required for Notch pathway signaling, $\gamma$-secretase cleavage of $\beta A P P$, and presenilin protein accumulation. Dev Cell 3:85-97.

Garcia-Ospina GP, Ginenez-Del Rio M, Lopera F, Velez-Pardo C (2003) Neuronal DNA damage correlates with a positive detection of c-Jun, nuclear factor $\kappa \mathrm{B}, \mathrm{p} 53$, and Par- 4 transcription factors in Alzheimer's disease. Rev Neurol 36:1004-1010.

Ginsberg D, Oren M, Yaniv M, Piette J (1990) Protein-binding elements in the promoter region of the mouse p53 gene. Oncogene 5:1285-1290.

Goutte C, Tsunozaki M, Hale VA, Priess JR (2002) APH-1 is a multipass membrane protein essential for the Notch signaling pathway in Caenorhabditis elegans embryos. Proc Natl Acad Sci USA 99:775-779.

Gu Y, Misonou H, Sato T, Dohmae N, Takio K, Ihara Y (2001) Distinct intramembrane cleavages of the $\beta$-amyloid precursor protein family resembling $\gamma$-secretase-like cleavage of Notch. J Biol Chem 276: 35235-35238.

Gu Y, Chen F, Sanjo N, Kawarai T, Hasegawa H, Duthie M, Li W, Ruan X, Luthra A, Mount HTJ, Tandon A, Fraser FW, St. George-Hyslop P (2003) APH-1 interacts with mature and immature forms of presenilins and nicastrin and may play a role in maturation of presenilin-nicastrin complexes. J Biol Chem 278:7374-7380.

Gu Y, Sanjo N, Chen F, Hasegawa H, Petit A, Ruan X, Li W, Shier C, Kawarai T, Schmitt-Ulms G, Westaway D, St. George-Hyslop P, Fraser FW (2004) The presenilin proteins are components of multiple membrane-bound complexes which have different biological activities. J Biol Chem 279:31329-31336.

Guo Q, Sebastian L, Sopher BL, Miller MW, Ware CB, Martin GM, Mattson MP (1999) Increased vulnerability of hippocampal neurons from presenilin-1 mutant knock-in mice to amyloid $\beta$-peptide toxicity: central roles of superoxide production and caspase activation. J Neurochem 72:1019-1029.

Gupta S, Radha V, Furukawa Y, Swarup G (2001) Direct transcriptional activation of human caspase-1 by tumor suppressor p53. J Biol Chem 276:10585-10588.

Heber S, Herms J, Gajic V, Hainfellner JA, Aguzzi A, Rülicke T, Kretzschmar H, von Koch C, Sisodia SS, Tremml P, Lipp H-P, Wolfer DP, Müller U (2000) Mice with combined gene knock-outs reveal essential and partially redundant functions of amyloid precursor protein family members. J Neurosci 20:7951-7963.

Herreman A, Serneels L, Annaert W, Collen D, Schoonjans L, De Strooper B (2000) Total inactivation of $\gamma$-secretase activity in presenilin-deficient embryonic stem cells. Nat Cell Biol 2:461-462.

Hong C-S, Caromille L, Nomata Y, Mori H, Bredesen DE, Koo EH (1999) Contrasting role of presenilin-1 and presenilin-2 in neuronal differentiation in vitro. J Neurosci 19:637-643.

Kamijo T, Zindy F, Roussel M, Quelle DE, Downing JR, Ashmun RA, Grosveld G, Scherr CJ (1997) Tumor suppression at the mouse INK4a locus mediated by the alternative reading frame product p19 ${ }^{\mathrm{ARF}}$. Cell 91:649659.

Kang DE, Yoon IS, Repetto E, Busse T, Yermian N, Ie L, Koo EH (2005) Presenilins mediate PI3K/AKT and ERK activation via select signaling receptors: selectivity of PS2 in PDGF signaling. J Biol Chem 280:31537-31547.

Kimberly WT, Zheng JB, Guénette S, Selkoe DJ (2001) The intracellular domain of the $\beta$-amyloid precursor protein is stabilized by Fe65 and translocates to the nucleus in a Notch-like manner. J Biol Chem 276:40288-40292.

Kinoshita A, Whelan CM, Berezovska O, Hyman BT (2002a) The $\gamma$-secretase-generated carboxy-terminal domain of the amyloid precur- sor protein induces apoptosis via Tip60 in H4 cells. J Biol Chem 277:28530-28536.

Kinoshita A, Whelan CM, Smith CJ, Berezovska O, Hyman BT (2002b) Direct visualization of the gamma secretase-generated carboxy-terminal domain of the amyloid precursor protein: association with Fe65 and translocation to the nucleus. J Neurochem 82:839-847.

Kitamura Y, Shimohama S, Kamoshima W, Matsuoka Y, Nomura Y, Taniguchi T (1997) Changes of p53 in the brains of patients with Alzheimer's disease. Biochem Biophys Res Commun 232:418-421.

Komarov PG, Komarova EA, Kondratov RV, Christov-Tselkov K, Coon JS, Chernov MV, Gudkov AV (1999) A chemical inhibitor of p53 that protects mice from the side effect of cancer therapy. Science 285:1733-1737.

Luo WJ, Wang H, Li H, Kim BS, Shah S, Lee H-J, Thinakaran G, Kim T-W, Yu G, Xu H (2003) PEN-2 and APH-1 coordinately regulate proteolytic processing of presenilin 1. J Biol Chem 278:7850-7854.

Ma G, Li T, Price D, Wong PC (2005) APH-1a is the principal mammalian $\mathrm{APH}-1$ isoform present in $\gamma$-secretase complexes during embryonic development. J Neurosci 25:192-198.

Marambaud P, Ancolio K, Lopez-Perez E, Checler F (1998) Proteasome inhibitors prevent the degradation of familial Alzheimer's disease-linked presenilin 1 and trigger increased $\mathrm{A} \beta_{42}$ secretion by human cells. Mol Med 4:147-157.

Miyashita T, Reed JC (1995) Tumor suppressor p53 is a direct transcriptional activator of the human bax gene. Cell 80:293-299.

Ohyagi Y, Asahara H, Chui DH, Tsuruta Y, Sakae N, Miyoshi K, Yamada T, Kikuchi H, Taniwaki T, Murai H, Ikezoe K, Furuya H, Kawarabayashi T, Shoji M, Checler F, Iwaki T, Makifuchi T, Takeda K, Kira J, Tabira T (2005) Intracellular $A \beta_{42}$ activates p53 promoter: a pathway to neurodegeneration in Alzheimer's disease. FASEB J 19:255-257.

Pardossi-Piquard R, Petit A, Kawarai T, Sunyach C, Alves da Costa C, Vincent B, Ring S, D’Adamio L, Shen J, Müller U, St. George-Hyslop P, Checler F (2005) Presenilin-dependent transcriptional control of the $\mathrm{A} \beta$ degrading enzyme neprilysin by intracellular domains of $\beta$ APP and APLP. Neuron 46:541-554.

Pardossi-Piquard R, Dunys J, Yu G, St. George-Hyslop P, Alves da Costa C, Checler F (2006) Neprilysin activity and expression are controlled by nicastrin. J Neurochem 97:1052-1056.

Passer B, Pellegrini L, Russo C, Siegel RM, Lenardio MJ, Schettini G, Bachmann M, Tabaton M, D'Adamio L (2000) Generation of an apoptotic intracellular peptide by $\gamma$-secretase cleavage of Alzheimer's amyloid $\beta$ protein precursor. J Alzheimers Dis 2:289-301.

Pastorcic M, Das HK (2000) Regulation of transcription of the human presenilin-1 gene by Ets transcription factor and the p53 protooncogene. J Biol Chem 275:34938-34945.

Perez A, Morelli L, Cresto JC, Castano EM (2000) Degradation of soluble amyloid $\beta$-peptides $1-40,1-42$, and the Dutch variant $1-40 \mathrm{Q}$ by insulindegrading enzyme from Alzheimer disease and control brains. Neurochem Res 25:247-255.

Perez-Tur J, Froelich S, Prihar G, Crook R, Baker M, Duff K, Wragg M, Busfield F, Lendon C, Clark RF, Roques P, Fuldner RA, Johnston J, Cowburn R, Forsell C, Axelman K, Lilius L, Houlden H, Karran E, Roberts GW, Rossor M, Adams MD, Hardy J, Goate A, Lannfelt L, Hutton M (1995) A mutation in Alzheimer's disease destroying a splice acceptor site in the presenilin-1 gene. NeuroReport 7:297-301.

Roperch J-P, Alvaro V, Prieur S, Tyunder M, Nemani M, Lethrosne F, Piouffre L, Gendron M-C, Israeli D, Dausset J, Oren M, Amson R, Telerman A (1998) Inhibition of presenilin1 expression is promoted by p53 and p $21^{\text {WAF-1 }}$ and results in apoptosis and tumor suppression. Nat Med $4: 835-838$.

Sastre M, Steiner H, Fuchs K, Capell A, Multhaup G, Condron MM, Teplow DB, Haass C (2001) Presenilin-dependent $\gamma$-secretase processing of $\beta$-amyloid precursor protein at a site corresponding to the S3 cleavage of Notch. EMBO Rep 2:835-841.

Saura CA, Choi S-Y, Beglopoulos V, Malkani S, Zhang D, Rao BSS, Chattarji S, Kelleher III RJ, Kandel ER, Duff K, Kirkwood A, Shen J (2004) Loss of presenilin function causes impairments of memory and synaptic plasticity followed by age-dependent neurodegeneration. Neuron 42:23-36.

Scheinfeld MH, Ghersi E, Laky K, Fowlkes BJ, D’Adamio L (2002) Processing of $\beta$-amyloid precursor-like protein- 1 and -2 by $\gamma$-secretase regulates transcription. J Biol Chem 277:44195-44201.

Shirotani K, Edbauer D, Prokop S, Haass C, Steiner H (2004) Identification 
of distinct $\gamma$-secretase complexes with different APH-1 variants. J Biol Chem 279:41340-41345.

Sisodia SS, St. George-Hyslop P (2002) $\gamma$-Secretase, Notch, A $\beta$, and Alzheimer's disease: where do the presenilins fit in? Nat Rev Neurosci 3:281-290.

Steiner H, Winkler E, Edbauer D, Prokop S, Basset G, Yamasaki A, Kostka M, Haass C (2002) PEN-2 is an integral component of the $\gamma$-secretase complex required for coordinated expression of presenilin and nicastrin. J Biol Chem 277:39062-39065.

Tournoy J, Bossuyt X, Snellinx A, Regent M, Garmyn M, Serneels L, Saftig P, Craessaerts K, De Strooper B, Hartmann D (2004) Partial loss of presenilins causes seborrheic keratosis and autoimmune disease in mice. Hum Mol Genet 13:1321-1331.

Walsh DM, Fadeeva JV, LaVoie MJ, Paliga K, Eggert S, Kimberly WT, Wasco W, Selkoe DJ (2003) $\gamma$-Secretase cleavage and binding to Fe65 regulate the nuclear translocation of the intracellular C-terminal domain (ICD) of the APP family of proteins. Biochemistry 42:6664-6673.

Weber JD, Jeffers JR, Rehg JE, Randle DH, Lozano G, Roussel M, Sherr CJ, Zambetti GP (2000) p53-independent functions of the p19 (ARF) tumor suppressor. Genes Dev 14:2358-2365.
Wolfe MS (2001) $\gamma$-Secretase inhibitors as molecular probes of presenilin function. J Mol Neurosci 17:199-204.

Wolozin B, Iwasaki K, Vito P, Ganjei JK, Lacana E, Sunderland T, Zhao B, Kusiak JW, Wasco W, D’Adamio L (1996) Participation of presenilin 2 in apoptosis: enhanced basal activity conferred by an Alzheimer mutation. Science 274:1710-1713.

Xia X, Qian S, Soriano S, Wu Y, Fletcher AM, Wang XJ, Koo EH, Wu X, Zheng $\mathrm{H}$ (2001) Loss of presenilin 1 is associated with enhanced $\beta$-catenin signaling and skin tumorigenesis. Proc Natl Acad Sci USA 98:10863-10868.

Yu G, Nishimura M, Arawaka S, Levitan D, Zhang L, Tandon A, Song Y-Q, Rogaeva E, Chen F, Kawarai T, Supala A, Levesque L, Yu H, Yang D-S, Holmes E, Milman P, Liang Y, Zhang D-M, Xu D-H, Sato C, Rogaev E, Smith M, Janus C, Zhang Y, Aebersold R, Farrer L, Sorbi S, Bruni A, Fraser P, St. George-Hyslop P (2000) Nicastrin modulates presenilin-mediated notch/glp1 signal transduction and $\beta$ APP processing. Nature 407:48-54.

Zhang Z, Nadeau P, Song W, Donoviel D, Yuan M, Bernstein A, Yankner BA (2000) Presenilins are required for $\gamma$-secretase cleavage of $\beta$ APP and transmembrane cleavage of Notch. Nat Cell Biol 2:463-465. 